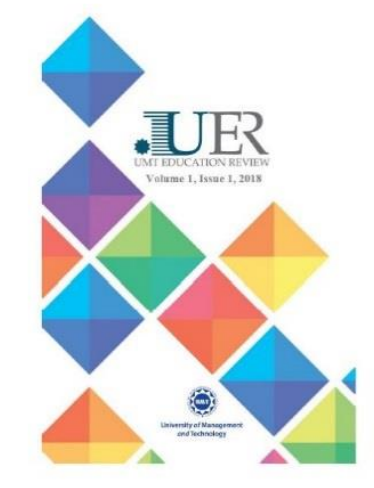

UMT Education Review (UER)

Volume No.1, Issue No. 1, 2018

ISSN: 2616-9738 (Print) 2616-9746 (Online)

Journal DOI: https://doi.org/10.32350/uer

Issue DOI: https://doi.org/10.32350/uer/11

Homepage: https://ssh.umt.edu.pk/uer/home.aspx

Journal QR Code:

\title{
Article: $\quad$ Effectiveness of 5e-model of Instruction for Scientific Achievement: An Exploration of Age, Cognitive Domain and Ability Level of Students with Hearing Impairment
}
Author(s):
Dr. Zahida Parveen

\section{Online Published: 2018}

\section{Article DOI: $\quad$ https://doi.org/10.32350/uer/11/04}

\section{Article QR Code:}

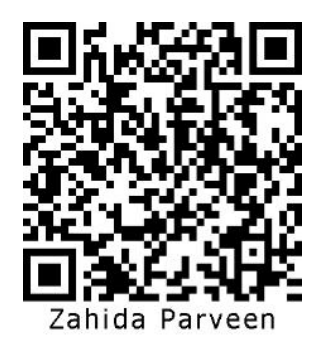

To cite this article: Parveen, Z. (2018). Effectiveness of 5e-model of instruction for scientific achievement: An exploration of age, cognitive domain and ability level of students with hearing impairment. UMT Education Review, 1(1), $51-66$.

\section{Crossref}

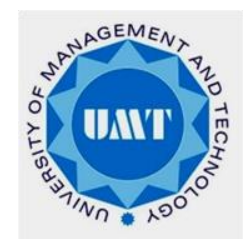

A publication of the

Department of Education

School of Social Sciences and Humanities

University of Management and Technology

Lahore 
Dr. Zahida Parveen

\title{
Effectiveness of 5e-model of Instruction for Scientific Achievement: An Exploration of Age, Cognitive Domain and Ability Level of Students with Hearing Impairment
}

\author{
Dr. Zahida Parveen
}

University of Education, Lahore

\begin{abstract}
This study was designed to investigate the effects of $5 \mathrm{E}$ Instructions on scientific achievement of students with hearing impairment. Further, it intended to explore the effectiveness of 5E Model with respect to gender, cognitive domain and ability levels of the students. For this purpose, a set of instructions were developed on the basis of $5 \mathrm{E}$ Model and a scientific achievement test based on three levels of cognitive domain was constructed. The results of control group and experimental group were analyzed to assess the effectiveness with respect to gender, cognitive domain and ability levels of the students. It was concluded that experimental group significantly performed better in the post-test on the basis of scores in cognitive domain and ability level.
\end{abstract}

Keywords: cognitive domain, ability level, 5e-model, hearing impairment

\section{Introduction}

Constructivist approach is used world widely in the teaching of all subjects and specifically in science and learning of science subjects (Brigham, Scruggs, \& Mastropieri, 2011).Morgan, Farkas, Hillemeier \& Maczuga (2016) quote successful application of constructivist approaches to students of school age. Inquiry oriented teaching is recommended in science teaching. From a pedagogical perspective, inquiry oriented teaching reflects the constructivist model of learning as understood by science educators today (Brigham, Scruggs, \& Mastropieri, 2011). Constructivist and inquiry oriented approaches are found working better for the learning of science concepts among students with hearing impairment. Demonstration and hands-on experiences help these children to develop an understanding of the complex processes of science. Children with hearing impairment are also very curious about the happenings in their surroundings and they desire to investigate and understand every phenomenon.

There are no differences in cognitive abilities of students with hearing impairment (Mayer, 2007), therefore the children with hearing impairment may be considered equally capable of learning science subjects like any other students. Many research organizations recognize the importance of science education for students with disabilities including children with hearing impairment. Teachers, school professionals and administrators also advocate science education for students with hearing impairment. There is a great contribution of students with disabilities in the field of science. Knoors. \& Marschark (2014) discussed achievements of two deaf scientists, Charles Nicolle and John Cornforth who were awarded by the United States of America 
Effectiveness of 5e-model of Instruction for Scientific Achievement

for their healthy contribution in the field of science. This shows that students with hearing impairment are equally competent to achieve higher status in the knowledge society. However, the responsibility rests upon the school science teachers of students with hearing impairment to equip these students with all necessary scientific skills and prepare them students for the field of science.

Unfortunately, children with hearing impairment in Pakistan are under estimated in terms of their learning. Classroom learning of children with hearing impairment is not satisfactory (Noreen \& Aziz, 2000). Some people opine that children with hearing impairment cannot learn science, but the fact is that such opinion cannot be held seriously in the absence of sound empirical evidence. On the contrary, research evidences suggest that cognition of children with hearing impairment is comparable with their peers without hearing loss (Mayer, 2007).

The marginal difference in the cognitive level may not be attributed to hearing difficulties; instead many other factors such as inappropriate instruction, teachers' unfriendly attitude and low expectations by the parents can be counted in this context. Moreover, it has been found that schools are not providing necessary support to science teachers to teach science to children with hearing impairment in an effective way (McDuffie, Mastropieri and Scruggs, 2009). This may be another plausible reason for teachers' reluctance to teach science to children with hearing impairment. Considering this dire need of time an experiment based on 5E Instructional Model was conducted to evaluate its effect on science achievement among students with hearing impairment.

\section{Literature Review}

Friedl and Koontz (2005) view the process of learning as one in which the students should develop the skills of asking questions, planning investigations, data collection, giving reasonable explanations and effectively communicating the results of their investigations. A general consensus of teachers and researchers is found on the emphasis for meaningful learning of the content. Meaningful construction of knowledge is preferred as compared to old learning methods (Thornton \& Sokoloff, 1990; Saka \& Akdeniz, 2006). This meaningful construction of knowledge is possible only through constructivist approaches like inquiry. Hammerman (2006) compares inquiry and direct instructions; according to her findings, teacher presents information in direct instruction and students verify the information through activity. Students generate questions and teachers answer them in class. Teacher delivers lecture and students copy it. While in inquiry based instruction, teacher or students present questions. Students are engaged in different activities to collect data and to answer the proposed question. Notebooks are used by students to record data, describe plans and to write conclusions. The construction of scientific knowledge is a complex process emphasizing the engagement of students. Leach and Scott (2002) conclude that scientific knowledge is constructed rather than discovered, and is socially validated. Moreover, individuals often have existing ways of knowledge about the natural 
phenomena that are explained by theories of science; although the terms used may be the same, the underlying patterns of reasoning are usually different.

The need to explore, wonder and probe the environment is the same for hearing impaired children as for without disabilities. The natural curiosity and enthusiasm that we value in children is not impaired by hearing impairment. Science experiences can broaden the child's view about the environment through extensive use of physical and natural materials. Li \& Zhang (2009) has shared that individuals with hearing impairment are working in every field of science. They are doctors, engineers, biologists and astronomers. All of them face barriers of communication and attitude; however, they continuously strive to overcome these barriers to be successful.

Science learning is the most neglected area for children with disabilities. However, it is possible for all children including those with special needs to be successful in scientific activities (Bennington, 2004). The importance of science education for students with disabilities is recognized by many research organizations. The majority of these researches advocate inquiry approach for teaching science to these children. Qi, \& Mitchell (2012) considered science as one of the most valuable subjects that could be taught to students with disabilities. They also mentioned that science education expanded experiential background for students who had limited experiences. Increased use of inquiry and problem-solving skills helped students with disabilities to survive with scientific literacy and enabled them to discover and manage information (Morgan, Farkas, Hillemeier, Maczuga, 2016). Sharma. Forlin, \& Loreman (2008) said that teachers identified science as the most valuable field of study in main stream education for students with any type of disability. Many authors recommended science as a potential subject for students with sensory and physical impairments because science developed compensatory skills for observing, manipulating and classifying phenomena (Ramirez, Asa \& Kraus, 2004; Sugai, 2000). Mastropieri, Scruggs, Boon, and Carter (2001) believed that students with disabilities could learn science. They argued that students with disabilities could perform similar to those without disabilities if they were engaged in constructivist tasks, however those students lagged behind in reading and mathematical tasks.

Although science is equally important for children with disabilities, however, issues of unwillingness, less time allocation, lack of teacher training and necessary skills make it difficult to happen. Research shows that the average time spent for teaching of science to students with disabilities is not comparable with other subjects. Fraser and Maguvhe (2008) conducted a survey about the time spent for science instructions and they reported that as compared to 200 minutes of reading instructions, students with mild disabilities receive only one minute of science instruction.

It was indicated then by special education teachers that mostly science was not taught and if taught, lesser time was allocated to students with disabilities as compared to general education science students (Engelbrecht, Oswald and Forlin 2006). In this 
Effectiveness of 5e-model of Instruction for Scientific Achievement

study, it was concluded that training in science was not provided to $42 \%$ of special education teachers and $38 \%$ of special children did not receive any science instruction. The survey also revealed that 50\% special education teachers devoted less than $60 \%$ minutes a week to science instructions, and the majority of science teachers of students with disabilities relied on text books. The research supported that adapted science curricula and activity oriented materials developed by the teachers worked well and contributed to positive gains in achievement of students with hearing impairment. These students could benefit from science education if implemented appropriately. Alber-Morgan, Sawyer \& Miller (2015) highlighted the issues of science education for students with disabilities. According to him, special educators had little experience of science, while science teachers had little knowledge of adaptations for disabilities. Elementary teachers lacked in the practical exposure to science which contributed very little to their knowledge about science (Akerson and Flanigan, 2000).

The 5E Instruction Model can be described as an instructional design which allows the instructor to facilitate the process of experiential learning through a series of several steps. The origin of the 5E Instructional Model is traced back to Johann Herbart the educationist of 20th century (Bybee, 2002). Two foundations of teaching were elaborated by Herbart. Firstly, he emphasized the interest of the learner and secondly, conceptual understanding. 5E Model is a direct descendant of the Atkin and Karplus learning cycle proposed in early 1960's and used in the Science Curriculum Improvement Study (SCIS). Atkin and Karplus used the terms exploration, invention, and discovery. Later on, those terms were modified to exploration, invention, and concept application by SCIS. Centre of Biological Sciences Curriculum Studies (BSCS) is a non-profit organization in U.S.A which develops curricula for grades K in sciences and professional development programs. In the mid-1980s, this center received a grant to conduct a study that would produce specifications for a new science and health curriculum. Among the innovations and key features that resulted from that study was the 5E Instructional Model (BSCS, 1997). Rodger Bybee was the actual presenter of the 5E Model. This model was adapted from SCIS Model and two new phases were introduced in this model: engagement as the first stage and evaluation as the last stage of the model. The three middle three stages exploration, explanation and elaboration were adapted from three stages of SCIS Model. 5E Instructional Model thus consists of five phases. The description of these phases is given by Bybee et al. (2006) as follows, (i) Engage- Engaging students in a new concept based on prior knowledge through short activities, (ii) Explore- Activities within which current concepts (i.e., misconceptions), processes, and skills are identified and conceptual change is facilitated, (iii) Explain-Learners explain their understanding of the concept. An explanation from the teacher or the curriculum may guide them toward a deeper understanding, which is a critical part of this phase,(iv) Elaborate-Teachers challenge and extend students' conceptual understanding and skills. Through new experiences, the students develop deeper and broader understanding, more information, and 
adequate skills, and (v) Evaluate- It provides opportunities for teachers to evaluate student progress toward achieving the educational objectives (p. 1). The Model has the cyclic nature which can be counted as an evident advantage. The cyclic structure of the model encourages the integrated approach of inquiry as compared to the linear model of inquiry. Though the components of the model appear in one particular sequence, yet the teacher can find somewhere else to start depending upon requirements of children and topic (Bloom, 2006).

The effectiveness of inquiry approaches including 5E Model is evident from research. Ozsevgec (2006) found that instructions based on 5E Model increase academic achievement of elementary students in science and attitudes towards science. Its positive effects on conceptual change were also reported by Hirca, Çalik, and Seven (2011). The positive output of 5E activities was also reported by Moseley, Reinke, and Bookout (2002), Boddy, Watson, and Aubsson (2003), Einsenkraft (2003), Clark (2003), Evans (2004), Carreno (2004), Akar (2005), Cardak, Dikmenli \& Saritas(2008) and Wilson, Taylor, Kowalski \& Carlson (2010).McCay (2005) taught science concepts to students with hearing impairment of pre-school by adopting the SCIS materials. The basic teaching sequence of SCIS was used; however, adaptations were made in the teaching method. The study reported a positive gain in achievement.

McGrath\& Hughes (2017) implemented science curriculum developed by BSCS for mild mentally handicapped children. They adopted those materials for adolescents with hearing impairment and positive gain in cognitive achievement and attitude was reported. Donohue and Borman (2014) used adopted curriculum of science and reported positive gain in terms of science learning for students with hearing impairment.

Bolajoko (2007) reported positive gain in the achievement of science among students with hearing impairment. They adapted information from the Houghton Mifflin Science series to incorporate multi-sensory approach for teaching science to hearing impaired students. A positive gain was also reported by Metz (2014). They successfully implemented the curriculum based on learning cycle.

The review of literature clearly indicates that students with hearing impairment can learn science through effective teaching strategies. The science education is not accessible to children with hearing impairment in Pakistan mainly because of segregated special education. There is need to conduct an experiment based on $5 \mathrm{E}$ Instructional Model on children with hearing impairment.

\section{Research Hypotheses}

This paper aims to test the following research hypothesis: 
Effectiveness of 5e-model of Instruction for Scientific Achievement

1. There is a significant difference in achievement in science between students with hearing impairment receiving instructions based on 5E Model and those receiving regular classroom instructions on the basis of age

2. There is a significant difference in achievement in science among students with hearing impairment receiving instructions based on 5E Model and those receiving regular classroom instructions on the basis of ability levels

3. There is a significant difference in achievement in science among students with hearing impairment receiving instructions based on 5E Model and those receiving regular classroom instructions on the basis of levels of cognitive domain

\subsection{Population}

\section{Methods}

There are a number of public and private schools for students with hearing impairment in Lahore city. All of these schools offer education to these children in a segregated system. This study was delimited to the elementary level students attending science class in Lahore city. This constituted the population of the study.

\subsection{Sample}

Thirty-four students with hearing impairment were selected from a private sector school in Lahore. That school was selected on the basis of sufficient number of students from both gender and facilitation was provided by the school for the purpose of research. The students were randomly assigned to two groups, i.e., control group and experimental group. Table 1 shows the random assignment of students to both groups

Table 1

Control group and experimental group with age and gender

\begin{tabular}{llllllllll}
\hline Sr. no & ID & Group & Gender & Age & Sr. no & ID & Group & Gender & Age \\
\hline 1 & 3 & C & F & 14 & 18 & 2 & E & F & 15 \\
2 & 4 & C & F & 15 & 19 & 1 & E & F & 16 \\
3 & 7 & C & F & 14 & 20 & 5 & E & F & 16 \\
4 & 8 & C & F & 16 & 21 & 6 & E & F & 16 \\
5 & 12 & C & M & 18 & 22 & 9 & E & F & 15 \\
6 & 13 & C & M & 17 & 23 & 32 & E & M & 17 \\
7 & 16 & C & M & 15 & 24 & 11 & E & F & 14 \\
8 & 21 & C & M & 19 & 25 & 28 & E & M & 17 \\
9 & 19 & C & M & 18 & 26 & 15 & E & M & 17 \\
10 & 20 & C & M & 18 & 27 & 17 & E & M & 15 \\
11 & 22 & C & M & 15 & 28 & 18 & E & M & 14 \\
12 & 23 & C & M & 19 & 29 & 26 & E & M & 15 \\
\hline
\end{tabular}


Dr. Zahida Parveen

\begin{tabular}{llllllllll}
\hline 13 & 27 & $\mathrm{C}$ & $\mathrm{M}$ & 16 & 30 & 24 & $\mathrm{E}$ & $\mathrm{M}$ & 16 \\
14 & 14 & $\mathrm{C}$ & $\mathrm{M}$ & 18 & 31 & 25 & $\mathrm{E}$ & $\mathrm{M}$ & 17 \\
15 & 30 & $\mathrm{C}$ & $\mathrm{M}$ & 14 & 32 & 29 & $\mathrm{E}$ & $\mathrm{M}$ & 16 \\
16 & 10 & $\mathrm{C}$ & $\mathrm{F}$ & 19 & 33 & 31 & $\mathrm{E}$ & $\mathrm{M}$ & 17 \\
17 & 34 & $\mathrm{C}$ & $\mathrm{M}$ & 19 & 34 & 33 & $\mathrm{E}$ & $\mathrm{M}$ & 19 \\
\hline & $*$ C stands for control group & & & & & & \\
& *E stands for experimental group & & & & & \\
& *F stands for female & & & & & & & &
\end{tabular}

\section{Instruments}

\subsection{Achievement Test}

For the purpose of pre-test and post-test, an achievement test was developed. The researcher decided to develop test for the chapter 'classification of organisms' after a detailed discussion with teachers teaching science at elementary level. The researcher also reviewed study options available to students with hearing impairment in the visited schools. It was found that those students were provided the opportunity to learn science up to elementary level and that subject was not offered beyond that level. Board of Intermediate and Secondary Education (BISE) offers tailoring, embroidery, type writing, carpet weaving, rug weaving, drawing, bakery, hosiery, computer science and physical education. BISE specifies that learning achievements will be assessed for knowledge, comprehension and application levels (Board of Intermediate and secondary Education Lahore, 2010).

The process of development of test was divided into the following steps.

A. The item construction followed the 'table-of-specification' developed, covering the chapter 'classification of organisms'. Six subtopics; Classification, Microorganisms, Viruses, Bacteria, Importance of Bacteria and Methods of Food Preservation, were covered in table of specifications. The items were developed from the subtopics according to the first three levels of cognitive domain of bloom's taxonomy. The proportion of items for each subtopic was in accordance to the length of the topic. The researcher developed forty-three multiple choice items to assess the achievement of students in the above mentioned five subtopics.

B. A test of 43 items was presented to five teachers teaching science at elementary level. These experts were asked to rate each item for its content validity and adequate representation of content area. The experts were asked for their opinion on three-point scale. The options of the scale were yes, no and to some extent. The items with minimum $99 \%$ agreement of panelists were selected. On 
Effectiveness of 5e-model of Instruction for Scientific Achievement

the basis of this criterion four items were rejected from the test and total 39 items were selected for the pilot test.

C. Total 39 items selected through the consensus of expert teachers were pilot tested on randomly selected 49 students with hearing impairment from three different schools. The scores obtained by pilot study were subjected to item analysis. Items with difficulty index lower than 0.1 or higher than 0.9 were deleted from the test (Donohue \& Borman, 2014). All items of the test fall in the acceptable range of item difficulty. It is suggested that the items having below +0.20 should be significantly improved or deleted and the items below 0.00 values should be definitely discarded (Fraser and Maguvhe, 2008). The researcher deleted the items having discrimination power below 0.00 and reviewed the items ranging between 0.00 and 0.20 . According to Metz (2014) if an alternative fails to attract 2 percent of test takers, it should be revised. On the basis of these criteria the researcher revised the alternatives which failed to attract 2 percent of the examinees.

D. The results of pilot study were subjected to reliability analysis and Cronbach alpha was $0.83(\mathrm{~N}=49)$. After item analysis and reliability coefficient, a test of 35 items was finalized for pre-test and post-test.

\subsection{Intervention}

An intervention guide was developed for the experiment. One lesson plan for each identified theme of the unit was developed according to $5 \mathrm{E}$ Instructional Model. Each lesson plan was time flexible and included the following components, i.e. Instructional Objectives, Content Focus, Overview, Key words, Required Materials, Classroom Layout, Instructional Procedure (engagement, explore, explain, elaborate and evaluate phases of the model), and closure.

Both groups were pre-tested to follow the research design. Experimental group was taught through the intervention guide while control group was taught through regular classroom instructions. At the end, both groups were post-tested and results were analyzed to test the hypothesis.

\section{Results and Discussion}

To evaluate the effectiveness of $5 \mathrm{E}$ Instructions for the students of different age groups, independent sample t-test was applied. The results are presented in table 2 .

Table 2

Age-wise comparison of control group and experimental group on pre-test, post-test and gain scores 
Dr. Zahida Parveen

\begin{tabular}{|c|c|c|c|c|c|}
\hline Group & Age & & Pre-test & Post-test & Gain score \\
\hline \multirow[t]{3}{*}{$\begin{array}{l}\text { Control } \\
\text { group }\end{array}$} & $\begin{array}{l}\text { Middle } \\
\text { adolescence }\end{array}$ & $N=8$ & & & \\
\hline & & $M$ & 45.88 & 65.50 & 19.62 \\
\hline & & $S D$ & 15.52 & 15.45 & 4.24 \\
\hline \multirow[t]{6}{*}{ Exp group } & $\begin{array}{l}\text { Middle } \\
\text { adolescence }\end{array}$ & $N=11$ & & & \\
\hline & & $M$ & 38.18 & 72.91 & 34.73 \\
\hline & & $S D$ & 14.03 & 12.68 & 9.11 \\
\hline & & $M D$ & 7.69 & 7.40 & 15.10 \\
\hline & & $T$ & 1.12 & 1014 & 4.33 \\
\hline & & $P$ & 0.27 & 0.26 & 0.000 \\
\hline \multirow{3}{*}{$\begin{array}{l}\text { Control } \\
\text { group }\end{array}$} & Late adolescence & $N=9$ & & & \\
\hline & & $M$ & 28.89 & 45.89 & 17.00 \\
\hline & & $S D$ & 12.01 & 18.36 & 8.12 \\
\hline \multirow[t]{6}{*}{ Exp group } & Late adolescence & $N=6$ & & & \\
\hline & & $M$ & 29.67 & 67.50 & 37.83 \\
\hline & & $S D$ & 10.28 & 15.12 & 10.81 \\
\hline & & $M D$ & 0.77 & 21.61 & 20.83 \\
\hline & & $T$ & 1.30 & 2.38 & 4.27 \\
\hline & & $P$ & 0.89 & 0.03 & 0.001 \\
\hline
\end{tabular}

The results indicate that students of middle adolescence from both control group and experimental group performed equally $(\mathrm{p}>0.05)$ on pre-test. However, a significant difference in gain scores $(\mathrm{p}<.000)$ was observed. Students of middle adolescence from experimental group showed higher gain scores. The comparison among students of late adolescence was also made and it showed no difference on pre-test ( $p>0.05)$. However, students of experimental group with late adolescents scored higher on post-test $(\mathrm{p}<0.05)$ and showed higher gain score $(\mathrm{p}<0.0001)$ as compared to control group.

A gender-wise comparison was made to investigate the effectiveness of $5 \mathrm{E}$ Instructions for first three levels of cognitive domain, i.e., knowledge, comprehension and application (table 3) 
Effectiveness of 5e-model of Instruction for Scientific Achievement

Table 3

Gender-Wise comparison of control group and experimental group on mean sores of different levels of cognitive domain on achievement test

\begin{tabular}{lllllllllll}
\hline Group & \multicolumn{3}{l}{ Knowledge } & \multicolumn{6}{c}{ Comprehension } & \multicolumn{3}{l}{ Application } \\
\hline & & $\begin{array}{l}\text { Pre- } \\
\text { test }\end{array}$ & $\begin{array}{l}\text { Post- } \\
\text { test }\end{array}$ & Gain & $\begin{array}{l}\text { Pre- } \\
\text { test }\end{array}$ & $\begin{array}{l}\text { Post- } \\
\text { test }\end{array}$ & Gain & $\begin{array}{l}\text { Pre- } \\
\text { test }\end{array}$ & $\begin{array}{l}\text { Post- } \\
\text { test }\end{array}$ & Gain \\
Boys & $N=12$ & & & & & & & & & \\
Cntrl & & & & & & & & & & \\
& $M$ & 15.42 & 22.92 & 7.67 & 11.83 & 19.08 & 7.33 & 8.00 & 12.42 & 4.50 \\
& $S D$ & 7.64 & 8.38 & 4.90 & 4.64 & 5.74 & 2.74 & 4.09 & 5.96 & 2.81 \\
Boys Exp $N=11$ & & & & & & & & & \\
& $M$ & 13.09 & 21.09 & 8.64 & 10.82 & 23.64 & 11.27 & 8.45 & 24.55 & 16.00 \\
& $S D$ & 4.59 & 3.88 & 3.98 & 3.21 & 3.82 & 5.06 & 3.29 & 7.20 & 5.51 \\
& $M D$ & 2.33 & 1.83 & 0.97 & 1.01 & 4.56 & 10.94 & 0.45 & 12.13 & 11.50 \\
& $T$ & 0.87 & 0.67 & 0.51 & 0.60 & 2.21 & 2.29 & 2.92 & 4.41 & 6.38 \\
& $p$ & 0.39 & 0.51 & 0.61 & 0.55 & 0.03 & 0.02 & 0.77 & 0.00 & 0.00 \\
Girls Cntrl & $N=5$ & & & & & & & & & \\
& $M$ & 14.80 & 21.20 & 6.40 & 14.40 & 19.60 & 5.20 & 12.20 & 16.80 & 5.00 \\
& $S D$ & 5.93 & 7.95 & 2.30 & 6.14 & 7.57 & 1.78 & 10.83 & 8.58 & 2.73 \\
Girls Exp & $N=6$ & & & & & & & & & \\
& $M$ & 17.67 & 25.50 & 7.83 & 15.00 & 24.67 & 9.67 & 8.67 & 24.00 & 16.00 \\
& $S D$ & 9.64 & 7.81 & 4.26 & 7.61 & 4.80 & 6.02 & 3.67 & 5.02 & 5.44 \\
& $S D$ & 2.67 & 4.30 & 1.43 & 0.60 & 5.07 & 4.47 & 3.53 & 7.20 & 11.00 \\
& $T$ & 0.57 & 0.90 & 0.67 & 0.14 & 1.35 & 1.58 & 0.69 & 1.65 & 4.08 \\
& $p$ & 0.57 & 0.39 & 0.51 & 0.89 & 0.20 & 1.47 & 0.51 & 0.14 & 0.00 \\
\hline
\end{tabular}

No significant difference was found between the mean scores of boys of control group and experimental group for knowledge ( $p>0.05)$, comprehension $(p>0.05)$ and application ( $p>0.05)$ components of pre-test. In post-test and gain scores of knowledge component, the difference was not significant among boys of control group and experimental group. This indicated that boys of both groups performed equally in pretest and post-test on knowledge component. However, for comprehension component, boys of experimental group did significantly well in post-test $(\mathrm{p}<0.05)$ and gain scores $(p<0.05)$. Similarly, for application component, scores of experimental group boys were significantly higher in post-test $(\mathrm{p}<0.001)$ and gain scores $(\mathrm{p}<0.001)$.

Similar results were found for girls of control group and experimental group for knowledge component of pre-test, post-test and gain scores. However, unlike boys, girls of control group and experimental group did not differ in scores of post-test $(p>0.05)$ and gain scores $(p>0.05)$ for comprehension component. Experimental group girls only differ in gain scores of application component $(p<0.001)$.

The above results showed that instructions based on 5E Model were more effective for boys for comprehension and application component of cognitive domain, 
while no difference in achievement scores was found for knowledge component. Further, these instructions were more effective for girls for application component of cognitive domain and no difference was found in scores on knowledge and comprehension component for girls.

Students of control group and experimental group were categorized as belowaverage and above-average groups according to their achievement in pre-test. Students achieving marks greater than mean score were grouped as above-average and those achieving marks lower than mean were grouped as below-average. Independent sample $\mathrm{t}$-test was run to see the difference of performance among those groups. The results are presented in table 4.

Table 4

Ability-wise comparison of control group and experimental group on pre-test, post-test and gain score

\begin{tabular}{lllll}
\hline Group & & Pre-test & Post-test & Gain score \\
\hline \multirow{3}{*}{ Below average Control } & $N=8$ & & & \\
& $M$ & 22.75 & 37.50 & 14.75 \\
& $S D$ & 5.17 & 8.96 & 5.44 \\
Below average Exp & $N=9$ & & & \\
& $M$ & 26.22 & 63.11 & 36089 \\
& $S D$ & 7.15 & 12.57 & 10.01 \\
& $M D$ & 3.47 & 15.61 & 12.14 \\
Above average Control & $T$ & 1.13 & 4.77 & 5.51 \\
& $P$ & 0.27 & 0.00 & 0.000 \\
Above average Exp & $M$ & 49.44 & 70.78 & 21.33 \\
& $S D$ & 10.35 & 9.65 & 6.04 \\
& $N=8$ & & & \\
& $M$ & 45.25 & 79.88 & 34.62 \\
& $S D$ & 10.93 & 7.66 & 9.47 \\
& $M D$ & 4.19 & 9.10 & 13.29 \\
& $T$ & 0.81 & 2.13 & 3.49 \\
& $p$ & 0.43 & 0.05 & 0.003 \\
\hline
\end{tabular}

The table indicates that there was no significant difference among belowaverage students of the control group and experimental group in pre-test $(p>0.05)$. However, there was a significant difference among below-average students of the control group and experimental group in post-test $(t=4.77, p<0.001)$. Scores of belowaverage students from experimental group were significantly higher. Gain scores of below-average students of experimental group were higher than those of control group $(p<0.0001)$. On theother hand, there was no significant difference among the aboveaverage students of the control group and the experimental group in pre-test 
Effectiveness of 5e-model of Instruction for Scientific Achievement

$(p>0.05)$.The above-average students from experimental group scored significantly higher in post-test $(\mathrm{p}=0.05)$ as compared to the experimental group. The gain scores of the experimental group above-average students were also significantly $(\mathrm{p}<$ 0.001 ) higher than the control group. It shows that instructions based on the 5EModel are equally effective for students with below-average and above-average ability levels.

\section{Conclusions}

This study discussed the effects of instructions based on 5E Model on scientific achievement of students with hearing impairment with reference to age, cognitive domain and ability level of students. It was concluded that those instructions were more effective for students with late adolescence as they performed higher in post-test. Moreover, the model proved more effective for boys for comprehension and application components, while, for girls those instructions were more effective for application component of cognitive domain. It was also found that the instructions were equally effective for below-average and above-average students with hearing impairment. This study recommends the use of activity based instructions for teaching science to students with hearing impairment at elementary level.

\section{References}

Alber, S. R.-M., Sawyer, M. R., \& Miller, H. L. (2015). Teaching science to young children with special needs. In Kathy Cabe Trundle, \& Saçkes Mesut (Eds.). Research in early childhood science education (pp. 299-324). London: Springer.

Akar, E. (2005). Effectiveness of 5e learning cycle model on students understanding of acid-base concepts (Master's thesis). Retrieved from: http://etd.lib.metu.edu.tr/upload/12605747/index.pdf

Akerson, V., \& Flanigan, J. (2000). Preparing pre-service teachers to use an interdisciplinary approach to science and language arts instruction. Journal of Science Teacher Education, 11, 345-362.

Atkin, J. M., \& Karplus, R. (1962). Discovery or invention? The Science Teacher, 29(5), 45-51.

Atwood, R. K., \& Oldham, B. R. (1985). Teachers' perceptions of mainstreaming in an inquiry oriented elementary science program. Science Education, 69(5), 619-624. DOI: $10.1002 /$ sce. 3730690504

Bennington, A. (2004). Science and pre-school children with special educational needs: Aspects of home based teaching sessions. British Journal of Special Education, 31(4), 191-198. DOI: 10.1111/j.0952-3383.2004.00354.x

Biological Sciences Curriculum Study (1997). BSCS biology: A human approach ( $1^{\text {st }}$ ed.). Dubuque, IA: Author. 
Dr. Zahida Parveen

Bloom, J. W. (2006). Creating a classroom community of young scientists. New York: Routledge Press.

Boddy, N., Waston, K., \& Aubsson, P. (2003). A trial of the five Es: A referent model for constructivist teaching and learning. Research in Science Education, 33(1), 27-42. Retrieved from: http://www.springerlink.com/content/ r03926m2812212j7/fulltext.pdf

Bolajoko O. (2007). Global burden of childhood hearing impairment and disease control priorities for developing countries. Retrieved from: http://dx.doi.org/10.1016/S0140-6736(07)60602-3

Brigham, F. J., Scruggs, T. E., \& Mastropieri, M. A. (2011). Science education and students with learning disabilities. Learning Disabilities Research \& Practice, 26(4), 223-232.

Brown, G., \& Yule, G. (1983). Discourse analysis. Cambridge: Cambridge University Press.

Bybee, R. W. (2002). Learning science and science of learning: Science educators essay collection. Arlington: NSTA Press.

Bybee, R. W., Taylor, J. A., Gardner, A., Scotter, P., Carlson, J.-P., Westbrook, A., et al. (2006). The BSCS 5E instructional model: Origins and effectiveness. Retrieved from: http://science.education.nih.gov/houseofreps.nsf/b82d55fa138 783c2852572c9004f5566/\$FILE/Appendix\%20D.pdf

Cardak, O., Dikmenli, M., \& Saritas, O. (2008). Effect of 5E instructional model in student success in primary school $6^{\text {th }}$ year circulatory system topic. Asia-Pacific Forum on Science Learning and Teaching, (9)2. Retrieved from: http://www.ied.edu.hk/apfslt/v9 issue2/cardak/

Carreno, B. (2004). Facilitating with "Eeee's". Strides: Toward A Land Ethic, 9(1).

Curran, J. R., \& Clark, S. (2003, May). Language independent NER using a maximum entropy tagger. Proceedings of the seventh conference on Natural language learning at HLT-NAACL, 4, 164-167.

Donohue, D., \& Borman, J. (2014). The challenges of realizing inclusive education in South Africa. South African Journal of Education, 34(2), 1-14.

Ebel, R. L., \& Frisbie, D. A. (1986). Essential of Educational Measurement. Englewood Cliffs, NJ: Prentice Hall.

Einsenkraft, A. (2003). Expanding the 5E model. The Science teacher, 70(6), 56-59. Retrieved from: http://www.its-about-time.com/iat/5e.pdf

Engelbrecht, P., Oswald, M., \& Forlin, C. (2006). Promoting the implementation of inclusive education in primary schools in South Africa. British Journal of Special Education, 33(3), 121-129. 
Effectiveness of 5e-model of Instruction for Scientific Achievement

Evans, C. (2004). Learning with inquiry minds: Students are introduced to the unit on gas laws and properties of gases using the 5E model. The Science Teacher, 71(1), 4.

Fraser, W. J., \& Maguvhe, M. O. (2008). Teaching life sciences to blind and visually impaired learners. Journal of Biological Education, 42(2), 84-89.

Friedl, A. E., \& Koontz, T. Y. (2005). Teaching science to children: An inquiry approach (6th ed.). New York: McGraw Hill Company.

Hammerman, E. (2006). Becoming a better science teacher: 8 steps to high quality instruction and student achievement. London: Sage publications.

Hirca, N., Çalik, M., \& Seven, S. (2011). Effects of guide materials based on 5E model on students' conceptual change and their attitudes towards physics: A case for 'work, power and energy unit.' Journal of Turkish Science Education, 8(1), 153158. Retrieved from: http://www.tused.org/internet/tused/archive/v8/i1/ text/tusedv8i1a8.pdf

Hiroyuki S. (2000). Perspectives of education for children with visual impairment and deaf blindness in Japan. Retrieved from: http://deafblindinternational.org /Docs/Review\%20Archive/Perspective\%20of\%20Education.pdf

Knoors, H., \& Marschark, M. (2014). Teaching deaf learners: Psychological and developmental foundations. Oxford: Oxford University Press.

Leach, J., \& Scott, P. (2002). The demands of learning science concepts: Issues of theory and practice. In S. Amos \& R. Boohan (Eds.). Teaching science in secondary schools. London: Routledge.

Li, D., \& Zhang, J. (2009). Chinese deaf adolescents free recall of taxonomic, slot filler, and thematic categories. Scandinavian Journal of Psychology, 50(4), 355366.

Linn, M. C., \& Thier, H. D. (1975). The effect of experiential science on development of logical thinking in children. Journal of Research in Science Teaching, 12(1), 49-62. doi: 10.1002/tea.3660120108

Mastropieri, M. A., Scruggs, T. E., Boon, R., \& Carter, K. B. (2001). Correlates of inquiry learning in science. Remedial and Special Education, 22(3), 130-137.

Mayer, C. (2007). What really matters in the early literacy development of deaf children? Journal of Deaf Studies and Deaf Education, 12(4), 411-431.

McCay V. (2005). Fifty years of research on the intelligence of deaf and hard-ofhearing children: A review of literature and discussion of implications. The Journal of Deaf Studies and Deaf Education, 10(3), 225-231.

McDuffie, K. A., Mastropieri, M. A., \& Scruggs, T. E. (2009). Differential effects of peer tutoring in co-taught and non-taught classes: Results for content learning and student-teacher interactions. Exceptional Children, 75(4), 493-510. 
Dr. Zahida Parveen

McGrath, A. L., \& Hughes, M. T. (2017). Students with learning disabilities in inquirybased science classrooms: A cross-case analysis. Learning Disability Quarterly, 13, 31-42. DOI: 10.2307/1510390.

Metz, S. (2014). Science for all. The Science Teacher, 81(4), 6.

Morgan, P. L., Farkas, G., Hillemeier, M. M., \& Maczuga, S. (2016). Science achievement gaps begin very early, persist, and are largely explained by modifiable factors. Educational Researcher, 45(1), 18-35.

Moseley, C., Reinke, K., \& Bookout, V. (2002). The effect of teaching outdoor environmental education on pre-service teachers' attitudes toward self-efficacy and outcome expectancy. The Journal of Environmental Education, 34(1), 9-15.

Noureen, A., \& Aziz, R. (2000). A study of interpersonal relationships between teachers and students in the institutions of hearing impaired children (Master's thesis). Lahore: University of the Punjab.

Osborne, R. J. \& Freyberg, P. (1985). Learning in science: The implications of children's science. London: Heinemann.

Ozsevgeç, T. (2006). Determining effectiveness of student guiding material based on the 5E model in "force and motion" unit. Journal of Turkish Science Education, 3(2), 24-27. Retrieved from: http://www.tused.org/internet/tused/archive/V3/ i2/text/tusedv3i2s3.pdf

Qi, S., \& Mitchell, R. E. (2012). Large-scale academic achievement testing of deaf and hard-of-hearing students: Past, present, and future. Journal of Deaf Studies and Deaf Education, 17(1), 1-18.

Ramirez, M., Peek, C.-A. \& Kraus, J. F. (2004). Disability and risk of school related injury. BMJ, 10(1), 21-26. DOI: 10.1136/ip.2003.002865

Rammers H. H., Gage, N. L., \& Rummel, J. I. (1967).A practical introduction to measurement and evaluation (2nd ed.). New Delhi: Universal Book Stall.

Saka, A., Cerrah, L., Akdeniz, A. R., \& Ayas, A. (2006). A cross-age study of the understanding of three genetic concepts: How do they image the gene, DNA and chromosome? Journal of Science Education and Technology, 15(2), 192-202.

Schoeneberger, M., \& Russell, T. (1986). Elementary science as a little added frill: A report of two case studies. Science Education, 70(5), 519-538.

Sharma, U., Forlin, C., \& Loreman, T. (2008). Impact of training on pre service teachers' attitudes and concerns about inclusive education and sentiments about persons with disabilities. Disability \& Society, 23(7), 773-785.

Sugai, G., Horner, R. H., Dunlap, G., Hieneman, M., Lewis, T. J., Nelson, C. M., \& Turnbull, H. R. (2000). Applying positive behavior support and functional behavioral assessment in schools. Journal of Positive Behavior Interventions, 2(3), 131-143. 
Effectiveness of 5e-model of Instruction for Scientific Achievement

Thornton, R. K. \& Sokoloff, D. R. (1990). Assessing students learning of Newton's laws: The force and motion conceptual evaluation of active learning laboratory and lecture curricula. American Journal of Physics, 66, 338-352. Retrieved from: https://www.msu.edu/course/te/407/snapshot.afs/FS05Sec3/te802/files/ForceMo tion.pdf

Wilsin, C., Taylor, J., Kowalski, S., \& Carlson, J. (2010). The relative effects of inquiry-based and commonplace science teaching on students' knowledge, reasoning and argumentation: A randomized control trial. Journal of Research in Science Teaching 47(3), 276-301. Retrieved from: http://www.bscs.org/pdf/ BSCS_SREE 5E_presentation.pdf 